Check for updates

Cite this: RSC Adv., 2019, 9, 2360

Received 8th November 2018

Accepted 8th January 2019

DOI: $10.1039 / c 8 r a 09247 h$

rsc.li/rsc-advances

\section{The anti-diarrhea activity of red algae-originated sulphated polysaccharides on ETEC-K88 infected mice}

\author{
Bo Liu, Qing-Mei Liu, Gui-Ling Li, Le-Chang Sun, Yuan-Yuan Gao, Ya-Fen Zhang, \\ Hong Liu, Min-Jie Cao and Guang-Ming Liu (D)*
}

\begin{abstract}
Polysaccharides from red algae Porphyra haitanensis and Gracilaria lemaneiformis possess various bioactive functions, however, their anti-diarrhea activity remains incompletely defined. In the current study, sulphated polysaccharides were extracted by high pressure treatment plus ethanol precipitation from these two algae, and named $\mathrm{PHSP}_{(\mathrm{hp})}$ and $\mathrm{GLSP}_{(\mathrm{hp})}$, respectively. $\mathrm{PHSP}_{(\mathrm{hp})}$ and $\mathrm{GLSP}_{(\mathrm{hp})}$ showed decreased viscosity and molecular weight. Meanwhile, they have a certain immunomodulatory effect on wound healing and migration of RAW264.7 cells. Moreover, they significantly increased the secretion of proinflammatory cytokines tumor necrosis factor- $\alpha$ (TNF- $\alpha$ ) and interleukin-6 (IL-6). A BALB/c model infected by enterotoxigenic Escherichia coli (ETEC)-K88 was also established to evaluate the anti-diarrhea activity of $\mathrm{PHSP}_{(\mathrm{hp})}$ and $\mathrm{GLSP}_{(\mathrm{hp})}$. The results showed that $\mathrm{PHSP}_{(\mathrm{hp})}$ and $\mathrm{GLSP}_{(\mathrm{hp})}$ were able to alleviate mice diarrhea symptoms. Meanwhile, they inhibited the release of pro-inflammatory cytokines and suppressed the secretion of immunoglobulin A via reducing the population of B cells. In addition, the nitroblue tetrazolium levels of mouse serum were decreased. Taken together, $\mathrm{PHSP}_{(\mathrm{hp})}$ and $\mathrm{GLSP}_{(\mathrm{hp})}$ alleviated the inflammatory response of ETEC-K88-induced diarrhea through both specific and non-specific immunity. Sulphated polysaccharides from red algae may be used as functional food components for remitting diarrhea.
\end{abstract}

\section{Introduction}

Diarrhea is a digestive disorder disease generally characterized by abnormally frequent defaecation (three times or more per day), and/or blood and poorly fecal matter in feces, as well as electrolyte imbalance. ${ }^{1}$ According to epidemiological analysis, diarrhea is one of the most common diseases with global incidence greater than one billion per year. ${ }^{2}$ Although nowadays its mortality rate has been reduced due to improved medical care, it still remained the second leading lethal cause for children under age five, particularly in the developing countries, as reported in 2012. ${ }^{3,4}$ Among various types of infectious diarrhea, bacterial infection can cause a cute diarrhea which is characterized by fever, vomiting, abdominal pain, nausea and anorexia. ${ }^{5}$ The most common bacterial dysentery pathogens include Escherichia coli, Salmonella, Shigella and Staphylococcus aureus. ${ }^{6}$ Some strains of E. coli cause infections in the gastrointestinal tract system, while others may lead to non-gastrointestinal infections such as

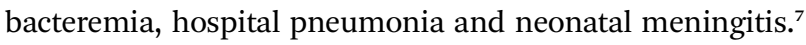

College of Food and Biological Engineering, Xiamen Key Laboratory of Marine Functional Food, Fujian Provincial Engineering Technology Research Center of Marine Functional Food, Fujian Collaborative Innovation Center for Exploitation and Utilization of Marine Biological Resources, Jimei University, 43 Yindou Road, Xiamen 361021, Fujian, P. R. China. E-mail: gmliu@jmu.edu.cn; Fax: +86-5926180470; Tel: $+86-592-6180378$
The enterotoxigenic Escherichia coli (ETEC) expresses one or more fimbrial adhesins, including F4 (K88), F5 (K99), F6 (987P), F7 (F41) and F18, that tightly bind to glycoprotein receptors on the enterocyte brush border to enable bacteria colonization in the small intestine. The bacteria then secrete heat-labile enterotoxins and/or heat-stable enterotoxins that alter the tight junction integrity and disrupt the paracellular passages of ions, solutes and water, leading to diarrhea. ${ }^{8-10}$

Current main therapies for diarrhea consist of oral rehydration solutions (ORS) and medications such as antibiotics. ORS is the first-line treatment for diarrhea worldwide, however, it is unable to reduce diarrhea's duration and severity. ${ }^{11}$ Antibiotic therapy was considered as one of the most effective diarrhea treatments in the past. However, it might develop antibiotic resistance in bacteria, which counteracts diarrhea treatment. ${ }^{11}$ Up to date, there has been no vaccine available against ETEC-induced diarrhea of children or travelers. Therefore treatment with bioactive molecule from marine resource with therapeutic potential for infectious diarrhea has gained growing research interest. ${ }^{12}$

Among bioactive components, the polysaccharides from seaweed are of special interest due to their great biological activities. It has been reported that sulphated polysaccharides from red algae have different biological activities, such as antiinflammatory, ${ }^{13}$ anti-microbial, ${ }^{14,15}$ antiviral, ${ }^{16}$ anti-cancer, ${ }^{17}$ and antioxidant ${ }^{18}$ bioactivities. Porphyra haitanensis $(P$. 
haitanensis) and Gracilaria lemaneiformis (G. lemaneiformis) are the two major species of red algae cultured in China, with annual product of 115875 and 270149 tons, respectively in 2016. ${ }^{19}$ Our previous work showed that sulphated polysaccharides extracted from $P$. haitanensis and G. lemaneiformis exhibited a certain anti-allergic activity. ${ }^{\mathbf{2 0 , 2 1}}$ However, the antidiarrhea activity of red algae-originated sulphated polysaccharides is rarely reported.

This study aims to investigate the immunomodulatory and anti-diarrhea activity of sulphated polysaccharides isolated from $P$. haitanensis and G. lemaneiformis in RAW264.7 cells and a mouse model with ETEC-K88-induced diarrhea. The present research may provide insights into future exploration for antidiarrhea functional foods and/or their feed.

\section{Materials and methods}

\section{Reagents}

Fetal bovine serum (FBS) was purchased from Gibco (Grand Island, NY, USA). DMEM was obtained from HyClone Co. (Logan, UT, USA). The enzyme-linked immunosorbent assay (ELISA) kits for immunoglobulin A (IgA), tumor necrosis factor$\alpha$ (TNF- $\alpha$ ), interferon- $\gamma$ (IFN- $\gamma$ ), interleukin-6 (IL-6) and monocyte chemotactic protein 1 (MCP-1) were purchased from R\&D Systems (Minneapolis, MN, USA). The antibodies, including APC-conjugated CD3, PerCP-Cy5.5-conjugated CD4 and PEconjugated CD19, were obtained from Biolegend (San Diego, CA, USA). Other chemicals were purchased from Sigma-Aldrich (St. Louis, MO, USA) and are all analytical grade.

\section{Extraction of the polysaccharides from red algae}

The red algae $P$. haitanensis and $G$. lemaneiformis were purchased from a local market of Dadeng Island (Xiamen, Fujian, China). Polysaccharide extraction was performed according to the method of Shi et al. with slight modifications. ${ }^{20}$ Briefly, the grated dry algae tissue $(10 \mathrm{~g})$ is mixed with $400 \mathrm{~mL}$ of distilled water and autoclaved under high pressure at $121^{\circ} \mathrm{C}$ for $5 \mathrm{~h}$. Being filtered with a nylon membrane, the polysaccharides were precipitated with 4 volumes of ethanol and kept at $4{ }^{\circ} \mathrm{C}$ for $24 \mathrm{~h}$. The filtrate was filtered again with a nylon membrane, naturally dried at room temperature, and re-dissolved in a small amount of water followed by freeze-dry under $-50{ }^{\circ} \mathrm{C}$. The sulphated polysaccharides extracted from $P$. haitanensis and $G$. lemaneiformis with high pressure were named $\operatorname{PHSP}_{(\mathrm{hp})}$ and $\operatorname{GLSP}_{(\mathrm{hp})}$, respectively. The yield of polysaccharides was calculated as the following formula: polysaccharides recovery rate $(\%)=$ mass $(\mathrm{g})$ of dried material obtained/mass $(\mathrm{g})$ of original dried microalgae $\times 100$.

\section{Characterization of the polysaccharide}

The viscosity of polysaccharide was determined using an Ubbelohde viscometer. Protein content of the polysaccharide fraction was measured by the Bradford method as previously described. ${ }^{22}$ The total carbohydrate and sulfate content in $\mathrm{PHSP}_{(\mathrm{hp})}$ and $\mathrm{GLSP}_{(\mathrm{hp})}$ were determined as previously described. $^{20}$ The molecular weight distribution of polysaccharides was determined by high performance gelpermeation chromatography (HPGPC) (Agilent-1100, Santa Clara, U.S.A.) equipped with a ZORBAX Eclipse XDB-C18 column $\left(250 \times 4.6 \mathrm{~mm}^{2}\right.$, column temperature $\left.30{ }^{\circ} \mathrm{C}\right)$. The Fourier transform infrared spectra of polysaccharide was analyzed with a Fourier transformed infrared spectrometer (FTIR) (Vector-22, Bruker, Switzerland) in the wave number range of $4000-400 \mathrm{~cm}^{-1}$ using the KBr-disk method.

\section{RAW264.7 cell culture, wound healing assay and transwell migration assay}

The murine monocyte-macrophage cell line RAW264.7 from Wuhan Beinglay Biotech Co. (Wuhan, Hubei, China) was grown in DMEM medium supplemented with $10 \% \mathrm{FBS}, 100 \mathrm{U} \mathrm{mL}^{-1}$ penicillin and $100 \mu \mathrm{g} \mathrm{mL} \mathrm{mL}^{-1}$ streptomycin at $37{ }^{\circ} \mathrm{C}$ in an incubator with a humidified atmosphere of $5 \% \mathrm{CO}_{2}$.

The wound healing assay was carried out to investigate the immunomodulation activity of $\operatorname{PHSP}_{(\mathrm{hp})}$ and $\operatorname{GLSP}_{(\mathrm{hp})}$ on RAW264.7 macrophages in 6-well culture plate. ${ }^{23}$ Briefly, after the cells adhere and the density was greater than 95\%, they were scratched by small tips and continued to incubate with $200 \mu \mathrm{g}$ $\mathrm{mL}^{-1} \mathrm{PHSP}_{(\mathrm{hp})}$ or $\mathrm{GLSP}_{(\mathrm{hp})}$ for $24 \mathrm{~h}$. Images were taken at $0 \mathrm{~h}$ and $24 \mathrm{~h}$. The degree of healing (three wells per set) at $24 \mathrm{~h}$ was determined as compared to that of cell at $0 \mathrm{~h}$.

The migration assay was carried out as described before. ${ }^{24}$ RAW264.7 cells $\left(1 \times 10^{5}\right)$ were added to the upper chamber of transwell inserts $(8 \mu \mathrm{m}$ pores, $6.5 \mathrm{~mm}$ polycarbonate membranes, Costar, Corning, NY, USA) that were placed in the 24-well culture plate. Six hundred microliter of DMEM complete medium together with $200 \mu \mathrm{g} \mathrm{mL}^{-1} \mathrm{PHSP}_{(\mathrm{hp})}$ or $\mathrm{GLSP}_{(\mathrm{hp})}$ was added to the lower chamber. Twenty four hours after incubation, the cells on the topside of upper chamber were removed with a cotton swab, followed by washing with PBS to remove the residual medium. Cells adherent the opposite surface of the insert was fixed with paraformaldehyde and stained with $0.1 \%$ crystal violet for $20 \mathrm{~min}$, and washed 2-3 times with tap water. The cell migration was observed under microscope (three wells per group). Finally, the bound dye was released with $30 \%$ glacial acetic acid, and its optical density was measured at $570 \mathrm{~nm}$ using an automated ELISA plate reader.

\section{Measurement of released TNF- $\alpha$ and IL-6}

The RAW264.7 cells $\left(1 \times 10^{5}\right.$ cells per well $)$ were seeded in 48 well plates with different concentrations of $\mathrm{PHSP}_{(\mathrm{hp})}$ and $\operatorname{GLSP}_{(\mathrm{hp})}\left(0,25,50,100\right.$ and $\left.200 \mu \mathrm{g} \mathrm{mL}^{-1}\right)$ or lipopolysaccharide (LPS) $\left(2 \mu \mathrm{g} \mathrm{mL} \mathrm{mL}^{-1}\right)$ as a positive control. After $24 \mathrm{~h}$ incubation, the culture supernatant was collected and assayed using the ELISA kits for TNF- $\alpha$ and IL-6, following the manufacturer's instructions (R\&D, Minneapolis, MN, USA).

\section{Establishment of ETEC-K88 bacteria induced-diarrhea mouse model}

The 6 week-old specific-pathogen-free (SPF) female BALB/c mice were purchased from the Shanghai Laboratory, Animal Center of the Chinese Academy of Sciences (Shanghai, China). Mice were maintained in a SPF environment at $22 \pm 1{ }^{\circ} \mathrm{C}$ with relative 
$55 \pm 10 \%$ humidity. All animal procedures were performed in accordance with the guidelines for care and use of Laboratory Animals of Jimei University and experiments were approved by the Animal Ethics Committee of Jimei University (Xiamen, Fujian, China), SCXK 2012-0005. Mice were fed with standard chows (Beijing Keao Biological Pharmaceutical Co., Ltd, Beijing, China) and water ad libitum throughout the experiments, except for fast prior to ETEC-K88 infection.

Standard strains of the Gram-negative enterotoxigenic bacteria Escherichia coli (ETEC-K88) freeze-drying powder (bio10666) was purchased from Beijing Biobw Biotechnology Co., Ltd. (Biobw, Beijing, China). The bacteria were grown in LuriaBertani (LB) medium, and incubated at $37{ }^{\circ} \mathrm{C}$ with shaking for $12 \mathrm{~h}$. Cultures were harvested by centrifugation at $5000 \mathrm{~g}$ for $10 \mathrm{~min}$, and the pellet was washed twice and re-suspended in sterile phosphate buffer saline (PBS). The counting of bacteria was carried out by means of inverted plate and their $\mathrm{OD}_{600}$ value.

The $50 \%$ lethal dose $\left(\mathrm{LD}_{50}\right)$ of ETEC-K88 was determined using a dose-response method. ${ }^{25}$ Thirty six female BALB/c mice were randomly divided into six groups. Mice were fasted for $12 \mathrm{~h}$ before infection, except for access to water ad libitum. The next day, mice in different groups were administrated in intraperitoneal injection with approximately $2 \times 10^{8}, 3 \times 10^{8}, 4 \times 10^{8}, 5$ $\times 10^{8}, 6 \times 10^{8} \mathrm{CFU}$ of ETEC-K88 in PBS at a volume of $200 \mu \mathrm{L}$ per mouse. The control group was administrated in intraperitoneal injection with sterile PBS alone. Food was then reintroduced ad libitum. Animals were observed four times per day for clinical signs and mortality for a period of $72 \mathrm{~h}$. Mice that were still alive 3 days after bacterial challenge were recorded as survivors. The total number of dead mice at each dose level was recorded and the $\mathrm{LD}_{50}$ was determined from a dose lethality curve using the Prism 6 statistical software of GraphPad Prism (San Diego, CA, USA).

Forty female BALB/c mice were randomly divided into four groups, including $\mathrm{PBS}$ control group, diarrhea group, $\mathrm{PHSP}_{(\mathrm{hp})}$ group and $\mathrm{GLSP}_{(\mathrm{hp})}$ group. To induce diarrhea, the mice were injected intraperitoneally with $0.2 \mathrm{~mL}$ of ETEC-K88 at the level of $\mathrm{LD}_{50}$. Three hours later, two groups were orally administered $\operatorname{PHSP}_{(\mathrm{hp})}$ and $\mathrm{GLSP}_{(\mathrm{hp})}\left(10 \mathrm{mg}\right.$ per mice), respectively. ${ }^{26,27}$ The other two groups were orally administered PBS $(200 \mu \mathrm{L}$ per mice). After that, all doses were given once every $24 \mathrm{~h}$ for one week.

The animals were observed $30 \mathrm{~min}$ after treatment and periodically during the first $24 \mathrm{~h}$, with special attention given during the first $4 \mathrm{~h}$, and daily thereafter, for a total of 7 days. The symptoms of illness or abnormal behavior were recorded as Leódido described. ${ }^{28}$ Furthermore, the body weight and diarrhea rate of mice were monitored throughout the study period.

\section{Measurement of the levels of cytokines and IgA in mouse serum}

The blood samples were collected from orbital venous plexus $24 \mathrm{~h}$ after the last administration and centrifuged at $4000 \mathrm{~g}$ for $10 \mathrm{~min}$. The sera were obtained and the levels of MCP-1, TNF- $\alpha$, IFN- $\gamma$, IL-6 and IgA were measured by ELISA according to the manufacturer's instructions.

\section{Flow cytometry analysis of $\mathrm{T} / \mathrm{B}$ cell subpopulation}

A small portion of the spleen was used for splenocytes preparation. The splenocytes were freed of red blood cells upon treatment with lysis buffer (Solabio Co., Beijing, China), stained with CD3-APC, CD4-PerCP-Cy5.5 and CD19-PE for $30 \mathrm{~min}$ at $4{ }^{\circ} \mathrm{C}$ and the $\mathrm{T}$ and $\mathrm{B}$ lymphocyte subpopulation was analyzed by flow cytometry. A Guava easyCyte 6-2L system were used for the analysis with the GuavaSoft 3.1.1 software (Millipore, MA, USA), following the manufacturer's instructions.

\section{Determination of nitroblue tetrazolium (NBT) activity}

The NBT assay was performed according to Anderson and Siwicki (1995) with slight modification. ${ }^{29}$ The blood (50 $\left.\mu \mathrm{L}\right)$ was transferred into a glass tube containing equal amount of $0.2 \%$ $(\mathrm{w} / \mathrm{v})$ NBT solution (prepared in PBS), or equal amount of PBS as the control. The tubes were incubated at room temperature for $30 \mathrm{~min}$ before addition of $1.5 \mathrm{~mL} N, N$-dimethyl formamide (DMF). The tubes were then centrifuged at $3000 \mathrm{~g}$ for $5 \mathrm{~min}$ at room temperature. The supernatant was collected and the sample absorbance at $540 \mathrm{~nm}$ was determined on an automated ELISA plate reader.

\section{Statistical analysis}

The data were expressed as mean \pm standard deviation (SD) and the group difference was analyzed by one-way ANOVA of Duncan test using the SPSS 17.0 software package (IBM, USA), and considered significant with $P<0.05$. Regarding the animal model assays, samples from individual mouse were processed and analyzed separately. Each experiment was repeated at least 3 times.

\section{Results}

\section{Polysaccharide extraction and property analysis}

Using high pressure treatment and ethanol precipitation, 4.11 $\pm 0.36 \mathrm{~g}$ and $2.77 \pm 0.19 \mathrm{~g}$ of polysaccharides were obtained from $10 \mathrm{~g}$ P. haitanensis and G. lemaneiformis, respectively. The microstructures of polysaccharides were also determined under a scanning electron microscope (SEM), as show in Fig. 1A. The microstructure of $\mathrm{PHSP}_{(\mathrm{hp})}$ has an irregular geometrical shape with a certain gap on the surface and loosely superimpose. However, the surface structure of $\operatorname{GLSP}_{(\mathrm{hp})}$ was smooth and flat, showing a continuous sheet.

The total sugar content of the extracted substance was above 98\% and few protein residues were detected in the polysaccharides fraction. As shown in Table 1, $\mathrm{PHSP}_{(\mathrm{hp})}$ and $\operatorname{GLSP}_{(\mathrm{hp})}$ have viscosity of $0.17 \mathrm{dL} \mathrm{g}^{-1}$ and $0.10 \mathrm{dL} \mathrm{g}^{-1}$. The average molecular weight of $\operatorname{PHSP}_{(\mathrm{hp})}$ was $165.45 \mathrm{kDa}$, while $\mathrm{GLSP}_{(\mathrm{hp})}$ have two components, $71.87 \mathrm{kDa}$ (accounting for $96.36 \%)$ and $1641.95 \mathrm{kDa}(3.64 \%)$. The FT-IR spectrum showed that $\mathrm{PHSP}_{(\mathrm{hp})}$ and $\mathrm{GLSP}_{(\mathrm{hp})}$ exhibited absorption peaks at $3330 \mathrm{~cm}^{-1}$ and $1640 \mathrm{~cm}^{-1}$, representing $-\mathrm{OH}$ and $\mathrm{C}=\mathrm{C}$ group, respectively (Fig. 1B). Furthermore, the absorption peaks at 1216 and $890 \mathrm{~cm}^{-1}$ for sulfated components were present. The sulfate content in $\mathrm{PHSP}_{(\mathrm{hp})}$ and $\mathrm{GLSP}_{(\mathrm{hp})}$ were further determined as $10.94 \%$ and $11.26 \%$, respectively. 
A

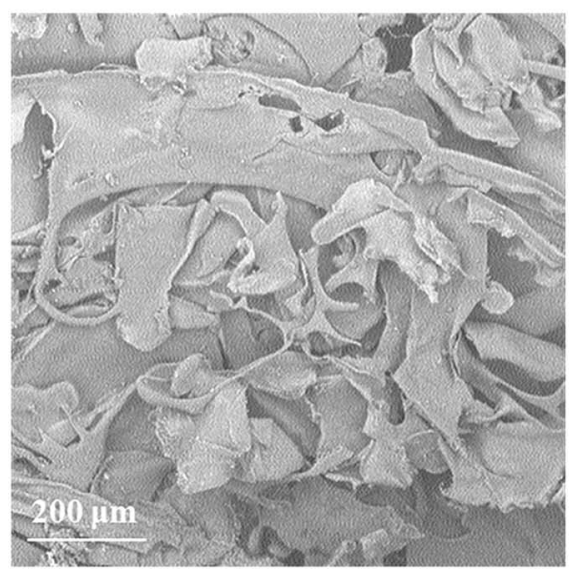

PHSP $_{(\text {hp) }}$

\section{B}

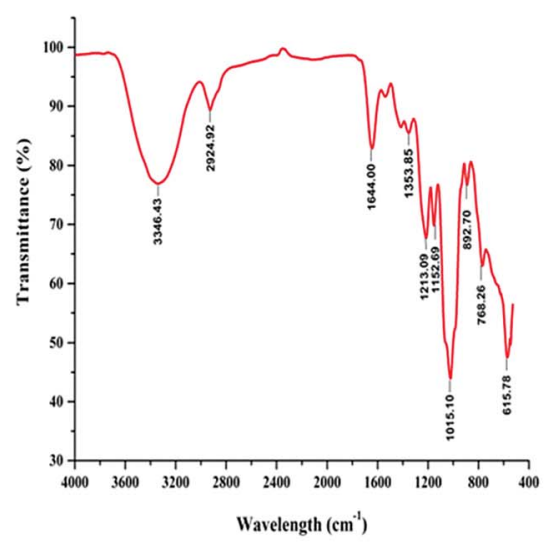

PHSP $_{(\text {hp) }}$

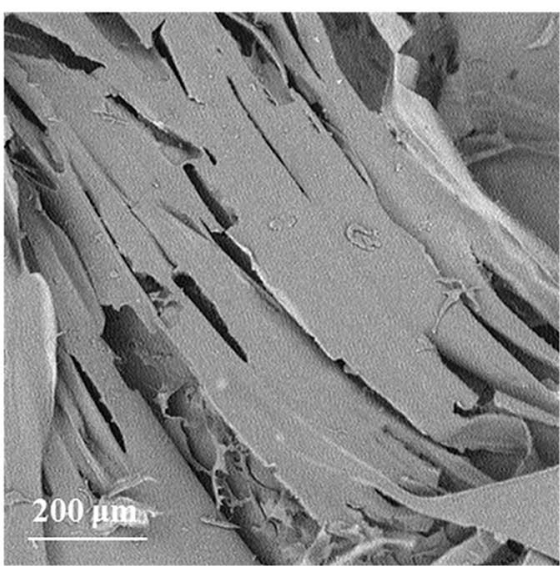

$\mathbf{G L S P}_{(\mathrm{hp})}$

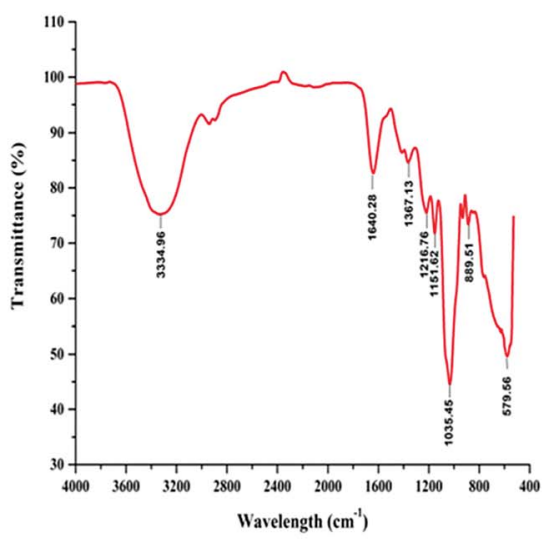

GLSP $_{(\text {hp })}$

Fig. 1 SEM and FT-IR spectrum of $\mathrm{PHSP}_{(\mathrm{hp})}$ and $\mathrm{GLSP}_{(\mathrm{hp})}$. (A) SEM of PHSP(hp) and $\mathrm{GLSP}_{(\mathrm{hp}) \text {. }}$ (B) FT-IR spectra of $\mathrm{PHSP}_{(\mathrm{hp})}$ and $\mathrm{GLSP}_{(\mathrm{hp}) \text {. }}$

Effects of PHSP $($ hp) and GLSP(hp) on RAW264.7 wound healing and migration

To investigate the effects of $\operatorname{PHSP}_{(\mathrm{hp})}$ and $\mathrm{GLSP}_{(\mathrm{hp})}$ on the inflammatory cells, their wound healing stimulating activity on RAW264.7 cells were evaluated using the scratch assay. Compared with the control, the number of cells in the middle wound area was increased upon treatment with $\mathrm{PHSP}_{(\mathrm{hp})}$ or $\operatorname{GLSP}_{(\mathrm{hp})}$ for $24 \mathrm{~h}$ (Fig. 2). The cells in the marginal area had

Table 1 Physicochemical properties of $\mathrm{PHSP}_{(\mathrm{hp})}$ and $\mathrm{GLSP}_{(\mathrm{hp})}$

\begin{tabular}{lrr}
\hline Physicochemical properties & \multicolumn{1}{c}{ PHSP $_{(\mathrm{hp})}$} & \multicolumn{1}{c}{$\mathrm{GLSP}_{(\mathrm{hp})}$} \\
\hline Total sugar (\%) & $99.12 \pm 0.36$ & $98.85 \pm 0.25$ \\
Protein content (\%) & $0.64 \pm 0.08$ & $0.39 \pm 0.06$ \\
Viscosity (dL g $^{-1}$ ) & $0.17 \pm 0.04$ & $0.10 \pm 0.02$ \\
Sulfate content (\%) $_{\text {Average molecular weight }(\mathrm{kDa})^{a}}$ & $10.94 \pm 0.43$ & $11.26 \pm 0.39$ \\
& 165.45 & 71.87
\end{tabular}

${ }^{a}$ Represents the major component (>96.0\%). a tendency to heal in the middle. Therefore $\operatorname{PHSP}_{(\mathrm{hp})}$ and GLSP $(\mathrm{hp})$ had effective healing capability for the scratched RAW264.7 cells.

The influence of PHSP $_{(\mathrm{hp})}$ and $\mathrm{GLSP}_{(\mathrm{hp})}$ on RAW264.7 migration was also determined. As shown in Fig. 3A, $200 \mu \mathrm{g} \mathrm{mL}$ $\operatorname{PHSP}_{(\mathrm{hp})}$ and $\mathrm{GLSP}_{(\mathrm{hp})}$ significantly promoted the migration of RAW264.7 from the upper chamber of transwell to its bottom side. The number of migrated cells in $\operatorname{PHSP}_{(\mathrm{hp})}$ and $\mathrm{GLSP}_{(\mathrm{hp})}$ groups were significantly higher than that in the control group (Fig. 3A). The absorbance values $\left(\mathrm{OD}_{570}\right)$ of eluted crystal violet also showed that PHSP $_{(\mathrm{hp})}$ and $\mathrm{GLSP}_{(\mathrm{hp})}$ significantly promoted RAW264.7 migration, as shown in Fig. 3B.

\section{Effects of $\operatorname{PHSP}_{(\mathrm{hp})}$ and GLSP $(\mathrm{hp})$ on the production of TNF- $\alpha$ and IL-6 in RAW264.7 cells}

The inflammatory factors of RAW264.7 cells were further explored. As shown in Fig. 4, exposure of RAW264.7 cells to $\operatorname{PHSP}_{(\mathrm{hp})}$ and $\mathrm{GLSP}_{(\mathrm{hp})}$ for $24 \mathrm{~h}$ resulted in significant increases in the secretion of TNF- $\alpha$ and IL-6, compared to PBS. The levels 


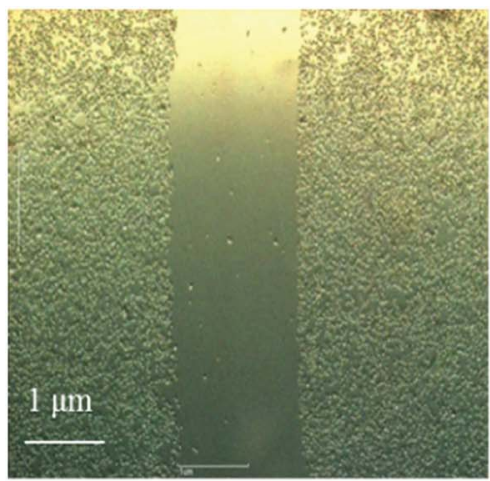

Control (0 h)

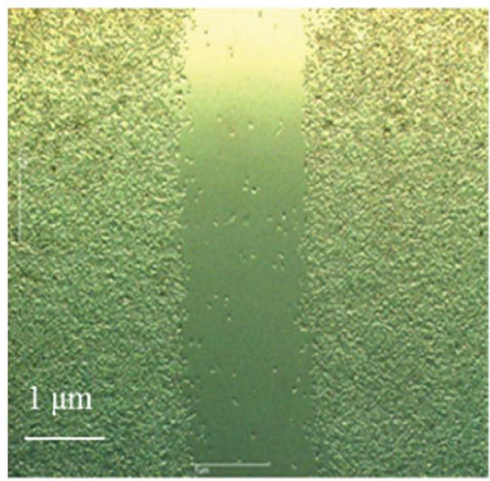

Control (24 h)

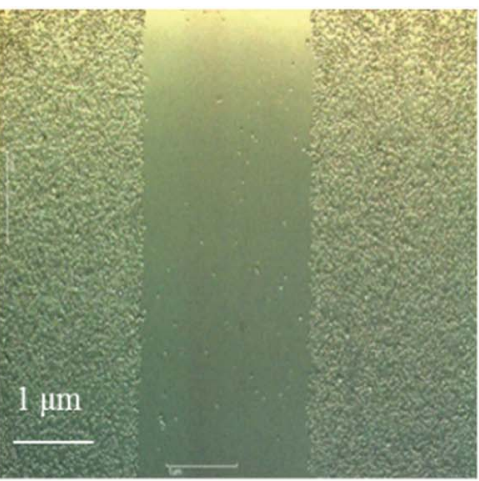

$\operatorname{PHSP}_{(\mathrm{hp})}(\mathbf{0} \mathrm{h})$

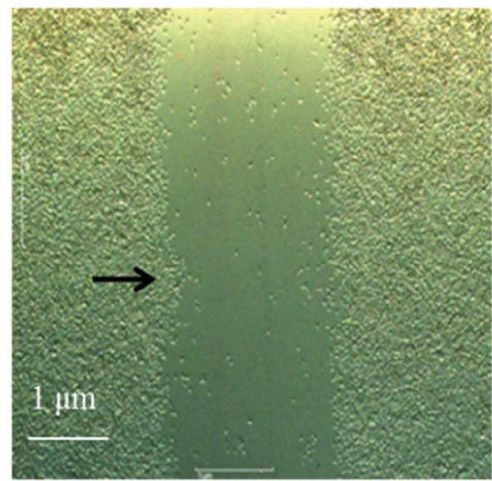

PHSP $_{\text {(hp) }}$ (24 h)

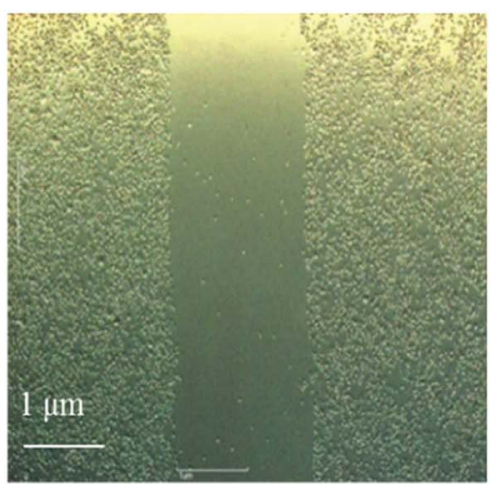

$\operatorname{GLSP}_{(\mathrm{hp})}(0 \mathrm{~h})$

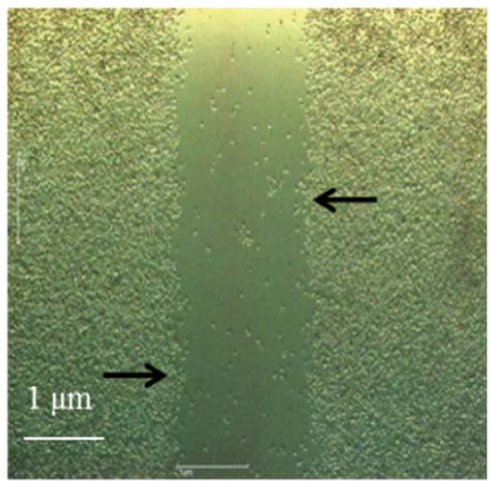

$\operatorname{GLSP}_{(\mathrm{hp})}(24 \mathrm{~h})$

Fig. 2 The influence of $\mathrm{PHSP}_{(\mathrm{hp})}$ and $\mathrm{GLSP}_{(\mathrm{hp})}$ on wound healing of RAW264.7 cells $(100 \times, 24 \mathrm{~h})$. The cells were scratched, and incubated with PBS (as the control group), PHSP(hp) or $\mathrm{GLSP}_{(\mathrm{hp})}$ followed by a $24 \mathrm{~h}$-recovery period. Microscopic bright field pictures were taken immediately after the scratch and the precise coordinates were reassessed $24 \mathrm{~h}$ after incubation.

of TNF- $\alpha$ were significantly increased to $2897.75 \mathrm{pg} \mathrm{mL} \mathrm{m}^{-1}$ and $2983.13 \mathrm{pg} \mathrm{mL} \mathrm{m}^{-1}$, respectively, in the $\operatorname{PHSP}_{(\mathrm{hp})}$ and $\mathrm{GLSP}_{(\mathrm{hp})}(100$

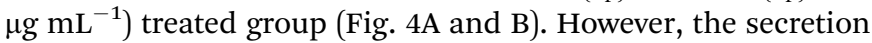
level of IL-6 increased in a dose-dependent manner in PHSP $_{(\mathrm{hp})}$ and GLSP $_{(\mathrm{hp})}$ treated RAW264.7 cells (Fig. 4C and D), which were
$861.48 \mathrm{pg} \mathrm{mL}^{-1}$ and $788.23 \mathrm{pg} \mathrm{mL}^{-1}$, respectively, in $200 \mu \mathrm{g}$ $\mathrm{mL}^{-1} \mathrm{PHSP}_{(\mathrm{hp})}$ and $\mathrm{GLSP}_{(\mathrm{hp})}$ treated cells. These findings suggested that PHSP $_{(\mathrm{hp})}$ and $\mathrm{GLSP}_{(\mathrm{hp})}$ regulated the immune system by enhancing the secretion of pro-inflammatory cytokines.
A

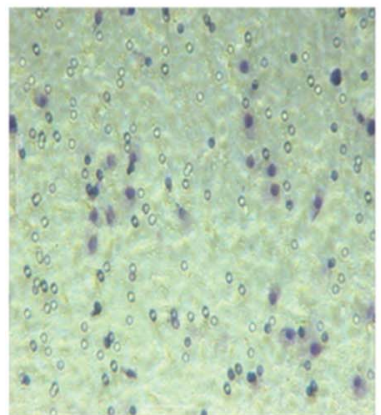

Control

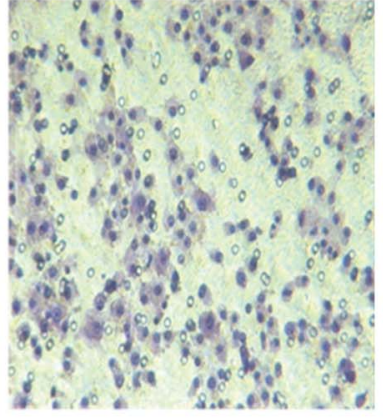

PHSP $_{(\mathrm{hp})}$

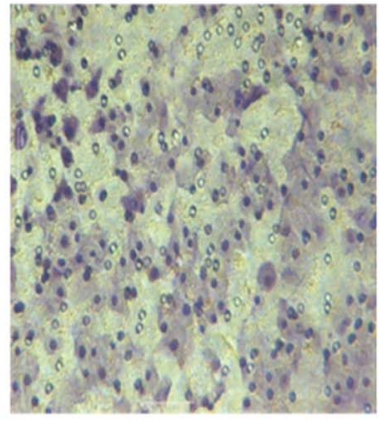

GLSP $_{(\mathrm{hp})}$
B

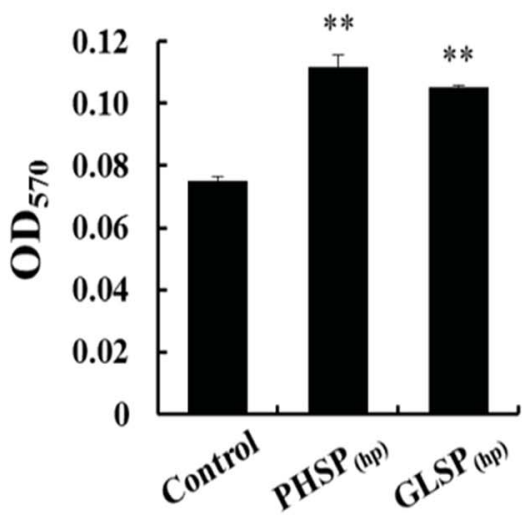

Fig. 3 The influence of PHSP(hp) and GLSP $(\mathrm{hp})$ on RAW264.7 migration $(100 \times, 24 \mathrm{~h})$. (A) RAW264.7 cell migration micrograph. (B) The absorbance values $\left(\mathrm{OD}_{570}\right)$ of eluted crystal violet. Data are present as mean $\pm \mathrm{SD}(n=3)$. 
A

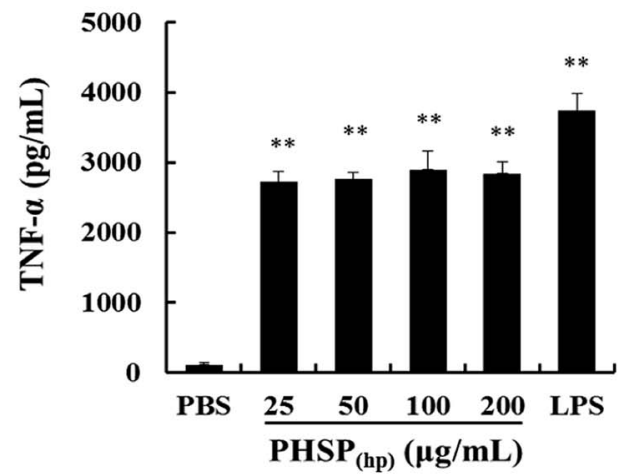

$\mathrm{C}$

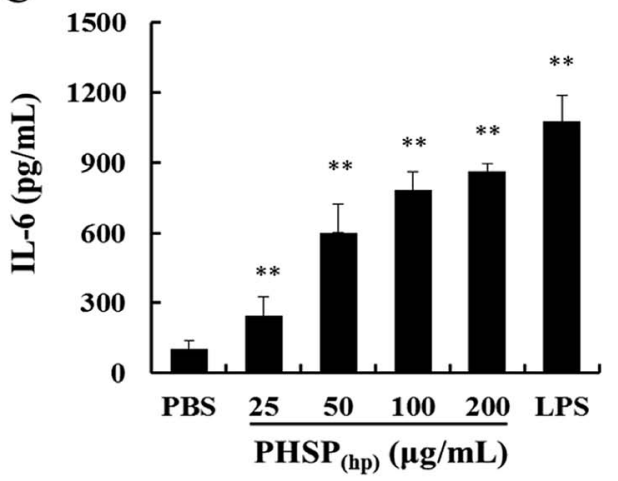

B

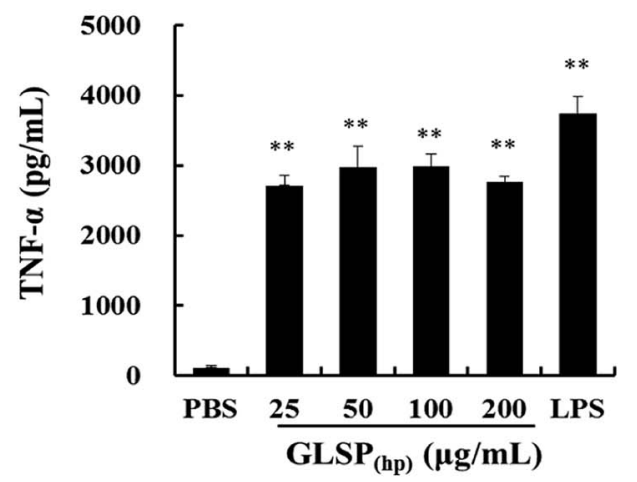

$\mathrm{D}$

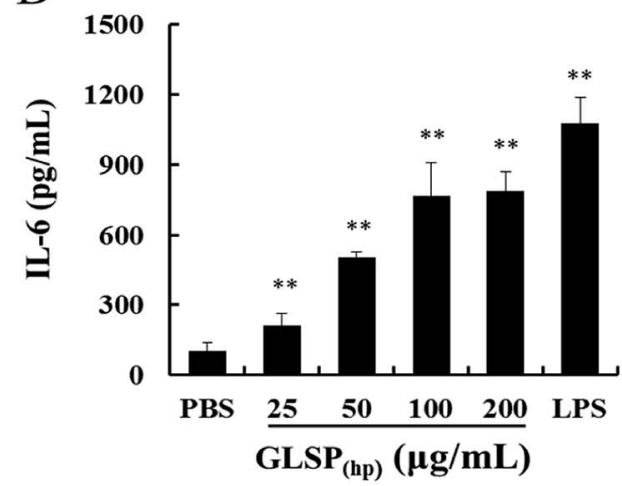

Fig. 4 Effects of PHSP $(\mathrm{hp})$ and $\mathrm{GLSP}_{(\mathrm{hp})}$ on TNF- $\alpha$ and IL-6 production in RAW264.7 cell supernatant. RAW264.7 cells were incubated with $\mathrm{PHSP}_{(\mathrm{hp})}$ and $\mathrm{GLSP}_{(\mathrm{hp})}\left(0,25,50,100,200 \mu \mathrm{g} \mathrm{mL}^{-1}\right)$ for $24 \mathrm{~h}$ and the cultural supernatants were collected for ELISA. (A and B) Effects of PHSP $(\mathrm{hp})$ and GLSP $(\mathrm{hp})$ on the secretion of TNF- $\alpha$. (C and D) Effects of PHSP(hp) and GLSP $(\mathrm{hp})$ on the secretion of IL-6. PBS served as a negative control and 2 $\mu \mathrm{g} \mathrm{mL}^{-1}$ LPS served as a positive control. Data are present as mean $\pm \mathrm{SD}(n=3)$. ${ }^{*} P<0.05$ versus the PBS group, **P<0.01 versus the PBS group.

\section{Alleviation of $\operatorname{PHSP}_{(h p)}$ and $\operatorname{GLSP}_{(\mathrm{hp})}$ on diarrhea symptoms}

To investigate the anti-diarrhea activity of $\mathrm{PHSP}_{(\mathrm{hp})}$ and $\mathrm{GLSP}_{(\mathrm{hp})}$ in vivo, an ETEC-K88 induced mice model were established in the present study. The study found that the ETEC-K88 at all dose caused death, and mice of the highest dose group died after two days. The $\mathrm{LD}_{50}$ of the ETEC-K88 was determined as $4 \times 10^{8} \mathrm{CFU}$ in female BALB/c mice (Fig. 5A).

The mice infected with ETEC-K88 $\left(\mathrm{LD}_{50}\right)$ could suffer diarrhea after $30 \mathrm{~min}$ (data not shown), excreting dilute stool like water. Compared with the diarrhea group, the $\operatorname{PHSP}_{(\mathrm{hp})}$ and $\mathrm{GLSP}_{(\mathrm{hp})}$ treated mice showed reduced infectious diarrhea rate in the first four days (Fig. 5B). On day 4, all the diarrhea mice returned to normal. The weight of mice infected with ETEC-K88 was significantly reduced on the first day. In addition, the weight of diarrhea group mice decreased for 5 days in a row, while the weight of $\operatorname{PHSP}_{(\mathrm{hp})}$ or $\mathrm{GLSP}_{(\mathrm{hp})}$ treated mice rebounded on the second day (Fig. 5C). These results suggest that $\mathrm{PHSP}_{(\mathrm{hp})}$ and $\mathrm{GLSP}_{(\mathrm{hp})}$ can reduce diarrhea rate and put on weight to alleviate diarrhea symptoms.

Effects of PHSP $(\mathrm{hp})$ and $\operatorname{GLSP}_{(\mathrm{hp})}$ on cytokines and IgA antibody levels in mice serum

The previous study reported that ETEC-K88-induced mice diarrhea caused inflammatory response with highly secretion of pro- inflammation mediators. ${ }^{30}$ As shown in Fig. 6A-D, the levels of pro-inflammatory cytokines (MCP-1, TNF- $\alpha$, IFN- $\gamma$, IL-6) were all significantly reduced in $\mathrm{PHSP}_{(\mathrm{hp})}$ and $\mathrm{GLSP}_{(\mathrm{hp})}$ treated mice serum.

The changes in total IgA levels in the serum in different groups were also measured and the data were shown in Fig. 6E. The serum IgA concentration was $104.21 \mathrm{ng} \mathrm{mL}^{-1}$ in the diarrhea group, which was significantly higher than that of the control PBS group at $73.04 \mathrm{ng} \mathrm{mL}^{-1}(P<0.01)$, indicating increased inflammatory response. Moreover, serum IgA levels in the $\mathrm{PHSP}_{(\mathrm{hp})}$ and $\mathrm{GLSP}_{(\mathrm{hp})}$ groups were decreased to $70.54 \mathrm{ng}$ $\mathrm{mL}^{-1}$ and $79.20 \mathrm{ng} \mathrm{mL}{ }^{-1}$, respectively. These results suggested that $\operatorname{PHSP}_{(\mathrm{hp})}$ and $\mathrm{GLSP}_{(\mathrm{hp})}$ remitted inflammatory response in ETEC-K88 induced mice diarrhea.

Effects of $\operatorname{PHSP}_{(\mathrm{hp})}$ and $\mathrm{GLSP}_{(\mathrm{hp})}$ on T/B cell subpopulation of mice splenocytes

Considering the suppression effects of $\mathrm{PHSP}_{(\mathrm{hp})}$ and $\mathrm{GLSP}_{(\mathrm{hp})}$ on serum IgA, the classification of mice spleen lymphocytes was further performed by flow cytometry. Compared with PBS group, the $\mathrm{CD} 19^{+} \mathrm{B}$ cells population in the diarrhea group was increased about $10 \%$ to $54.08 \%$, indicating that the $\mathrm{B}$ cell subpopulation was increased upon ETEC-K88 infection (Fig. 7A). And the $\mathrm{CD}^{+}{ }^{+} \mathrm{B}$ cells population were $47.36 \%$ and $45.84 \%$ in $\operatorname{PHSP}_{(\mathrm{hp})}$ and $\mathrm{GLSP}_{(\mathrm{hp})}\left(10 \mathrm{mg} \mathrm{d}^{-1}\right)$ treatment mice spleen, respectively, suggesting that $\mathrm{PHSP}_{(\mathrm{hp})}$ and $\mathrm{GLSP}_{(\mathrm{hp})}$ 
A

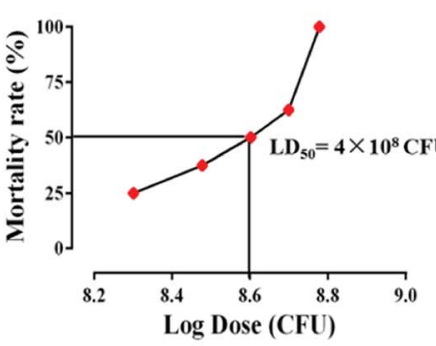

$\mathrm{B}$

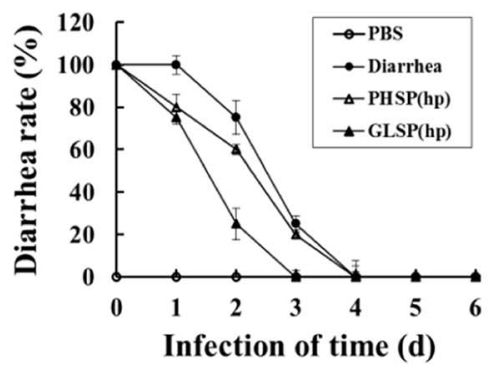

$\mathrm{C}$

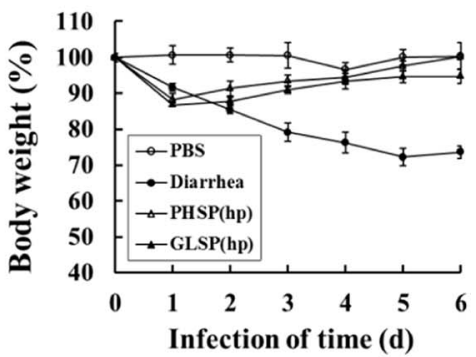

Fig. 5 Effects of $\mathrm{PHSP}_{(\mathrm{hp})}$ and $\mathrm{GLSP}_{(\mathrm{hp})}$ on diarrhea rate and weight changes in ETEC-K88 infected diarrhea mice. (A) Dose lethality curve of ETEC-K88 in BALB/C mice. (B) Variation of diarrhea rate along with infection time. (C) Weight changes along with infection time. Data (A) is present as mean $(n=6)$, data (B and C) are present as mean $\pm \operatorname{SD}(n=10)$.

(10 $\mathrm{mg} \mathrm{d}^{-1}$ ) down-regulated $\mathrm{B}$ cell population. Moreover, $\operatorname{PHSP}_{(\mathrm{hp})}$ and $\mathrm{GLSP}_{(\mathrm{hp})}$ showed no effect on $\mathrm{CD}^{+} \mathrm{CD}^{+}$Th cell population (Fig. 7B). Taken together, it was tempting to speculate that $\mathrm{PHSP}_{(\mathrm{hp})}$ and $\mathrm{GLSP}_{(\mathrm{hp})}$ reduce B cells subpopulation, which suppress IgA expression in mice serum and contribute to the anti-inflammatory activities in ETEC-K88-induced mice diarrhea.

\section{Effects of $\operatorname{PHSP}_{(\mathrm{hp})}$ and $\mathrm{GLSP}_{(\mathrm{hp})}$ on the NBT activity in mice serum}

The NBT assay was used to determine the neutrophil activity as nonspecific immune factor. ${ }^{25}$ As shown in Table 2, compared with PBS group, the $\mathrm{OD}_{540}$ of the diarrhea group was significantly increased $(P<0.01)$ upon infection by ETEC-K88, which indicated the neutrophilic granulocyte function was enhanced and the nonspecific immune balance was broken. Nevertheless, the $\mathrm{OD}_{540}$ was reduced in $\mathrm{PHSP}_{(\mathrm{hp})}$ and $\mathrm{GLSP}_{(\mathrm{hp})}$-treated mice serum. Thus, $\operatorname{PHSP}_{(\mathrm{hp})}$ and $\mathrm{GLSP}_{(\mathrm{hp})}$ may not only suppress the inflammatory response but also regulate nonspecific immunity.

\section{Discussion}

In this study, two sulphated polysaccharides, $\operatorname{PHSP}_{(\mathrm{hp})}$ and $\operatorname{GLSP}_{(\mathrm{hp})}$, were extracted from P. haitanensis and G. lemaneiformis, respectively, by high pressure treatment and ethanol precipitation. MTT assay showed that PHSP $_{(\mathrm{hp})}$ and $\operatorname{GLSP}_{(\mathrm{hp})}$ were not cytotoxic to the normal spleen lymphocytes of mouse $(P>0.05)$. The infrared spectrum results showed that hot water treatment and ethanol precipitation did not change the active
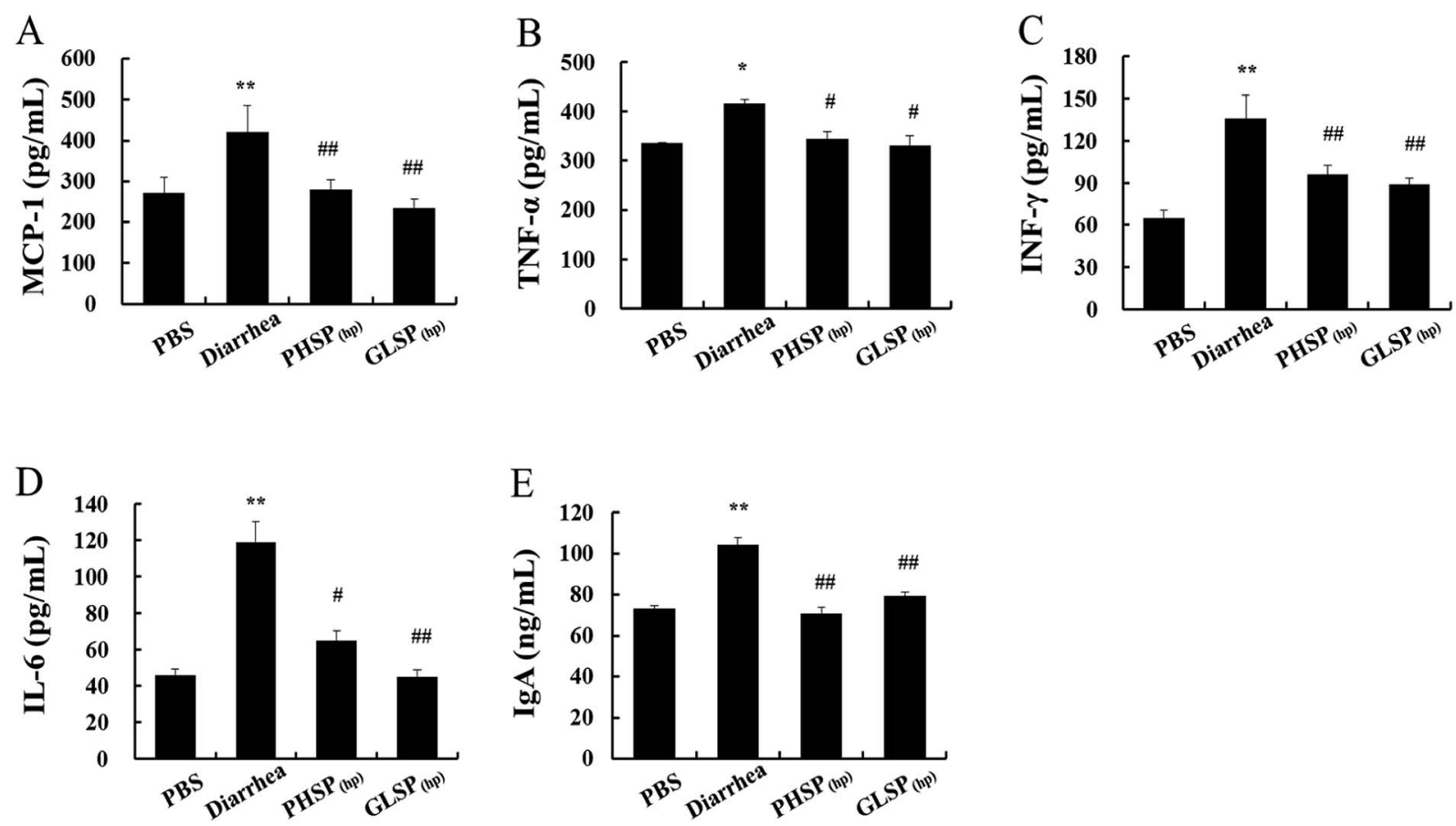

Fig. 6 Effects of PHSP(hp) and GLSP $(h p)$ in mice serum cytokines. (A) MCP-1, (B) TNF- $\alpha$, (C) IFN- $\gamma$, (D) IL-6, (E) IgA. ELISA was carried out in different ETEC-K88-infected sample groups. Data are present as mean $\pm \mathrm{SD}(n=3)$. $* P<0.05$ versus the PBS group, and $* * P<0.01$ versus the PBS group. ${ }^{\#} P<0.05$ versus the diarrhea group, and ${ }^{\# \#} P<0.01$ versus the diarrhea group. 
A

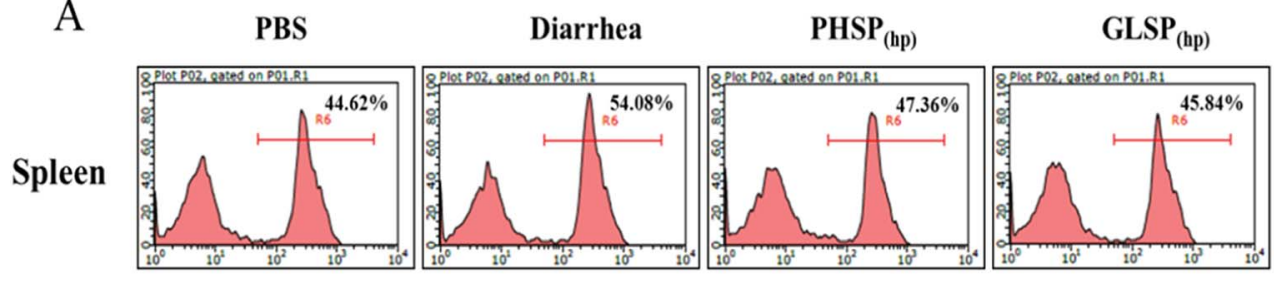

CD 19 PE
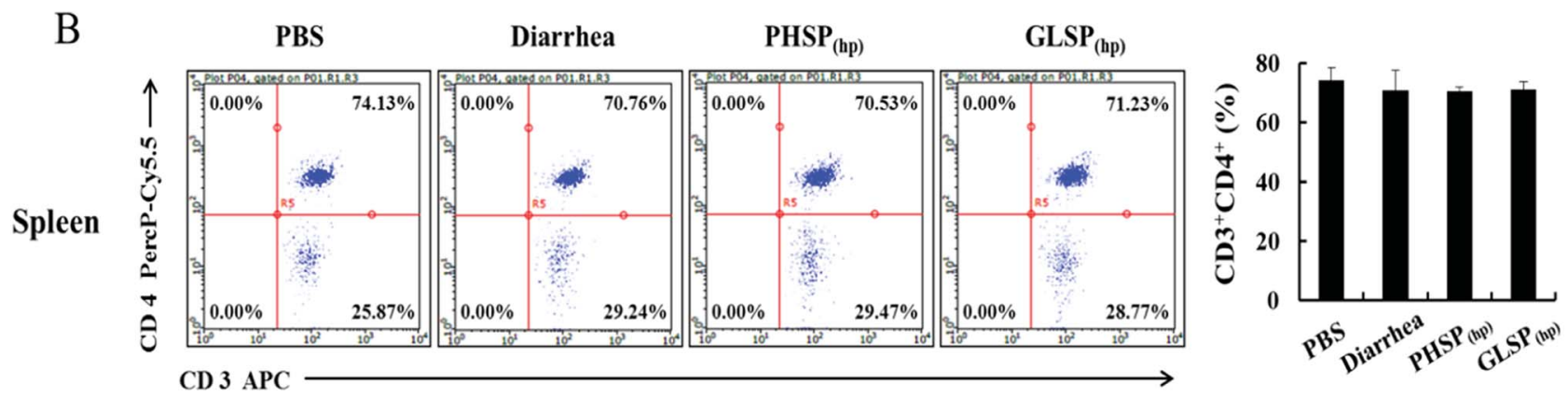

Fig. 7 Effects of $\mathrm{PHSP}_{(\mathrm{hp})}$ and $\mathrm{GLSP}_{(\mathrm{hp})}$ on lymphocyte from mice splenocytes. The infected mice were fed with $\mathrm{PHSP}_{(\mathrm{hp})}$ and GLSP $\mathrm{hp}_{(\mathrm{hp})}$ for 7 days before they were sacrificed and the splenocytes were obtained. Cells of $1 \times 10^{6}$ were mixed with CD3-APC, CD4-PercP-Cy5.5 and CD19-PE for 30 min at $4{ }^{\circ} \mathrm{C}$, before subject to the flow cytometry. (A) The histogram of B cell FACS analysis. (B) The scatter diagrams of Th cell FACS analysis.

ingredients of these polysaccharides. $\operatorname{PHSP}_{(\mathrm{hp})}$ and $\operatorname{GLSP}_{(\mathrm{hp})}$ have absorption peaks at $1030 \mathrm{~cm}^{-1}$ and $890 \mathrm{~cm}^{-1}$, indicating they are typical agar type polysaccharides. ${ }^{31-33}$ The infrared spectrogram data also shows some important functional groups of the polysaccharides. The absorption peaks at approximately $3340 \mathrm{~cm}^{-1}, 2920 \mathrm{~cm}^{-1}$ and $1640 \mathrm{~cm}^{-1}$ represent $-\mathrm{OH}, \mathrm{C}-\mathrm{H}$ and $\mathrm{C}=\mathrm{C}$ functional groups, respectively. In addition, the peak at about $1210 \mathrm{~cm}^{-1}$ was attributed to the sulphated ester groups, and the peak at about $1020 \mathrm{~cm}^{-1}$ corresponds to galactan backbone. However, altered physicochemical properties were also observed. For example, PHSP ${ }_{(\mathrm{hp})}$ and $\mathrm{GLSP}_{(\mathrm{hp})}$ showed more loose structure compared with polysaccharides extracted by hot water, as monitored by SEM. This result was consistent with previous finding that the changes of viscosity upon high pressure treatments and ethanol precipitation. ${ }^{27}$ The sulphated polysaccharides extracted from $P$. haitanensis and G. lemaneiformis showed average molecular weight of $2960 \mathrm{kDa}$ and 152 $\mathrm{kDa}^{20,21}$ with viscosity of $1.76 \mathrm{dL} \mathrm{g}^{-1}$ and $0.63 \mathrm{dL} \mathrm{g}^{-1}$,

Table 2 Effects of $\mathrm{PHSP}_{(\mathrm{hp})}$ and $\mathrm{GLSP}_{(\mathrm{hp})}$ on NBT activity $\left(\mathrm{OD}_{540}\right)$. The activity of NBT was measured in mice sera from different groups upon ETEC-K88 infection ${ }^{a}$

Nitroblue tetrazolium activity $\left(\mathrm{OD}_{540}\right)$

\section{PBS}

Diarrhea

$\operatorname{PHSP}_{(\mathrm{hp})}$

$\operatorname{GLSP}_{(\mathrm{hp})}$

$0.1284 \pm 0.0082$

$0.1940 \pm 0.0122^{* *}$

$0.1757 \pm 0.0165^{\#}$

$0.1422 \pm 0.0073^{\# \#}$

${ }^{a}$ Data are present as mean $\pm \mathrm{SD}(n=3) .{ }^{*} P<0.05$ versus the PBS group, and ${ }^{* *} P<0.01$ versus the PBS group. ${ }^{\#} P<0.05$ versus the diarrhea group, and ${ }^{\#} P<0.01$ versus the diarrhea group. respectively, while the viscosity of $\operatorname{PHSP}_{(\mathrm{hp})}$ and $\mathrm{GLSP}_{(\mathrm{hp})}$ were $0.17 \mathrm{dL} \mathrm{g}^{-1}$ and $0.10 \mathrm{dL} \mathrm{g}^{-1}$, respectively. Decreased molecular weight and viscosity of $\operatorname{PHSP}_{(\mathrm{hp})}$ and $\mathrm{GLSP}_{(\mathrm{hp})}$ that underwent high pressure treatment may be beneficial to the digestion and absorption in the intestine of mice.

Macrophages are immune cells that actively participate in the inflammatory immune response by releasing inflammatory factors and pro-inflammatory cytokines. ${ }^{34}$ During inflammation, activated macrophages can secrete nitric oxide (NO) and many pro-inflammatory cytokines, such as IL-6, TNF- $\alpha$ and IL$1 \beta .{ }^{35}$ PHSP was shown to significantly increase the levels of TNF$\alpha$, IL-6, IL-10 and iNOS/NO in RAW264.7 cells. ${ }^{27}$ In this study, the immune regulation by $\operatorname{PHSP}_{(\mathrm{hp})}$ and $\mathrm{GLSP}_{(\mathrm{hp})}$ were demonstrated in vitro, including induced RAW264.7 cell migration, enhanced wound healing, as well as increased secretion of TNF$\alpha$ and IL-6. The phagocytosis of pathogens by macrophages plays an important role in immune regulation, which involves the migration and adhesion of macrophages. $\mathrm{PHSP}_{(\mathrm{hp})}$ and $\mathrm{GLSP}_{(\mathrm{hp})}$ may act as chemokines to recruit macrophages and induce pathogen phagocytosis. Upon macrophage recruitment, they migrate to pathogens and sites of inflammation, and eventually exert their antibacterial effects. ${ }^{23}$

Bacteria intraperitoneal injection of has been a classic way to induce intestinal infection. ${ }^{36,37}$ To examine the anti-bacterial diarrhea activity of $\mathrm{PHSP}_{(\mathrm{hp})}$ and $\mathrm{GLSP}_{(\mathrm{hp})}, \mathrm{BALB} / \mathrm{c}$ mice were infected with ETEC-K88 $\left(\mathrm{LD}_{50}=4 \times 10^{8} \mathrm{CFU}\right)$ and then orally supplied with PHSP $_{(\mathrm{hp})}$ and $\mathrm{GLSP}_{(\mathrm{hp})}$. The infected mice showed severe diarrhea, piloerection, lethargy and weight loss. However, $\mathrm{PHSP}_{(\mathrm{hp})}$ and $\mathrm{GLSP}_{(\mathrm{hp})}$ not only reduced the total amount of mouse diarrheal stools, but also prevented the loss of weight. Moreover, the levels of pro-inflammatory factors and 
IgA were significantly decreased $(P<0.05)$ upon $\mathrm{PHSP}_{(\mathrm{hp})}$ and $\mathrm{GLSP}_{(\mathrm{hp})}$ treatment. The flow cytometry results showed that $\mathrm{B}$ cells subpopulation was significantly increased after infection, which suggested that toxin antigen-attacked mice stimulate $\mathrm{B}$ cells to produce antibodies to engulf pathogens. This is consistent with high IgA content in the diarrhea group. And decreased IgA levels in PHSP $_{(\mathrm{hp})}$ and $\mathrm{GLSP}_{(\mathrm{hp})}$ treated mice may resulted from the reduced $\mathrm{B}$ cell population. The reduction of pro-inflammatory factors, IgA, and B cell population suggested that $\mathrm{PHSP}_{(\mathrm{hp})}$ and $\mathrm{GLSP}_{(\mathrm{hp})}$ show anti-diarrhea activity through specific immune regulation in mice.

The neutrophil activity was considered a nonspecific immune parameter and determined by the NBT assay. ${ }^{25}$ The current study indicated that $\mathrm{PHSP}_{(\mathrm{hp})}$ and $\mathrm{GLSP}_{(\mathrm{hp})}$ reduced NBT level in ETEC-K88 infected BALB/c mice. Sulphated polysaccharides may stimulate the microbicidal activity of polymorphonuclear leukocytes and leucocytosis, which involves different nonspecific immune regulation mechanisms. ${ }^{25}$ The further effects of $\operatorname{PHSP}_{(\mathrm{hp})}$ and $\mathrm{GLSP}_{(\mathrm{hp})}$ on these leukocytes remains to be explored later.

Binding of toxins to ganglioside (GM) is the first step in toxins-induced diarrhea, which has become an attractive drug developing target for the treatment and prophylaxis of cholera toxins. ${ }^{38}$ Many studies have shown that galactose analogues interfere with the binding of toxin to GM1. ${ }^{38}$ The basic constituents of sulphated polysaccharides extracted from $P$. haitanensis and G. lemaneiformis are sulphated D-galactose monomers. PHSP $_{(\mathrm{hp})}$ and GLSP $_{(\mathrm{hp})}$ can alleviate ETEC-K88 bacteria diarrhea. This may be due to that the galactose monomers of sulphated polysaccharide block the toxin binding site and interfere with the binding of LT (heat-labile toxin) toxin to GM1. ETEC subtype STbP is involved in the induction of secretary diarrhea in animals, including humans. This toxin binds to sulphatide ( 3 -sulphogalactosyl-ceramide) receptors containing regions distributed on the intestinal epithelium cell wall. ${ }^{39}$ Inhibition of STbP binding to its receptor was achieved by type $\lambda$-carrageenan, a polymer extracted from seaweed and consisting of sulphated galactose units. ${ }^{40}$ It is speculated that $\mathrm{PHSP}_{(\mathrm{hp})}$ and $\operatorname{GLSP}_{(\mathrm{hp})}$ could alleviate diarrhea by mimicking this toxin to compete with the receptor.

Studies have reported that ganglioside receptors exhibit high affinity for carbohydrates, because toxins bind to ganglioside receptors in host epithelial cells in the form of glycoproteins and exhibit greater affinity for GM1 ${ }^{41}$ However, the galactoside acted as a high-affinity inhibitor of toxins-GM1 interaction. $\mathrm{PHSP}_{(\mathrm{hp})}$ and $\mathrm{GLSP}_{(\mathrm{hp})}$ comprises high-molecular-weight sulfated galactans, with high sugar content; galactose accounts for the majority of the sugars. It may be able to explain the interaction of $\mathrm{PHSP}_{(\mathrm{hp})}$ and $\mathrm{GLSP}_{(\mathrm{hp})}$ with GM1, preventing toxins binding, which interferes in the key step of transport of the toxin into the enterocytes.

\section{Conclusions}

In this study, sulphated polysaccharides from Porphyra haitanensis $\left(\mathrm{PHSP}_{(\mathrm{hp})}\right)$ and Gracilaria lemaneiformis $\left(\mathrm{GLSP}_{(\mathrm{hp})}\right)$ were obtained by high pressure treatment plus ethanol precipitation, with the molecular weight of $165.45 \mathrm{kDa}$ and $71.87 \mathrm{kDa}$, respectively. The wound healing and cell migration results indicated that $\mathrm{PHSP}_{(\mathrm{hp})}$ and $\mathrm{GLSP}_{(\mathrm{hp})}$ had immunomodulatory effects. They also alleviated diarrhea symptoms in mice via dietary intervention. Meanwhile, $\mathrm{PHSP}_{(\mathrm{hp})}$ and $\mathrm{GLSP}_{(\mathrm{hp})}$ inhibited the release of pro-inflammatory cytokines and IgA by reducing $\mathrm{B}$ cell population. In addition, they decreased nitroblue tetrazolium level in the ETEC-K88 infected mice. In summary, $\mathrm{PHSP}_{(\mathrm{hp})}$ and $\mathrm{GLSP}_{(\mathrm{hp})}$ were effectively against ETECK88-induced secretary diarrhea, probably by both specific and non-specific immunities. These findings may provide substantial support for the use of functional food as sulphated polysaccharides from red algae to alleviate diarrhea.

\section{Conflicts of interest}

There are no conflicts to declare.

\section{Abbreviations}

ELISA

ETEC

FT-IR

IFN- $\gamma$

IgA

IL-6

$\mathrm{LD}_{50}$

LPS

MCP-1

NBT

$\operatorname{PHSP}_{(\mathrm{hp})}$ and

$\operatorname{GLSP}_{(\mathrm{hp})}$

TNF- $\alpha$

\author{
Enzyme-linked immunosorbent assay \\ Enterotoxigenic Escherichia coli \\ Fourier transformed infrared spectrometer \\ Interferon- $\gamma$ \\ Immunoglobulin A \\ Interleukin- 6 \\ $50 \%$ lethal dose \\ Lipopolysaccharide \\ Monocyte chemotactic protein 1 \\ Nitroblue tetrazolium \\ Sulphated polysaccharides extracted from \\ Porphyra haitanensis and Gracilaria \\ lemaneiformis with high pressure \\ Tumor necrosis factor- $\alpha$
}

\section{Acknowledgements}

This work was supported by the grants from the National Natural Scientific Foundation of China (31871720), the Science and Technology Program of Fujian province (2018N5009, 2018R0071), and the Marine Scientific Research Special Foundation for Public Sector Program (DY135-B2-07, 201505026-03).

\section{References}

1 M. M. Suleiman, T. Dzenda and C. A. Sani, Antidiarrhoeal activity of the methanol stem-bark extract of Annona senegalensis, Pers. (Annonaceae), J. Ethnopharmacol., 2008, 116, 125-130.

2 GBD 2015 Disease and Injury Incidence and Prevalence Collaborators, Global, regional, and national incidence, prevalence, and years lived with disability for 310 diseases and injuries, 1990-2015: a systematic analysis for the Global Burden of Disease Study 2015, Lancet, 2016, 388, 1545-1602. 
3 A. I. English, New frontiers in the development of vaccines against enterotoxinogenic (ETEC) and enterohaemorrhagic (EHEC) E. coli infections. Part II, Wkly. Epidemiol. Rec., 1999, 74, 105-111.

4 C. L. Walker, I. Rudan, L. Liu, H. Nair, E. Theodoratou, Z. A. Bhutta, K. L. O'Brien and H. Campbell, Global burden of childhood pneumonia and diarrhea, Lancet, 2013, 381, 1405-1416.

5 M. Qu, Y. Deng, X. Zhang, G. Liu, Y. Huang, C. Lin, J. Li and H. Yan, Etiology of acute diarrhea due to enteropathogenic bacteria in Beijing, China, J. Infect., 2016, 65, 214-222.

6 O. G. Gómezduarte, J. Bai and E. Newel, Detection of E. coli, Salmonella spp. Shigella spp. Yersinia enterocolitica, Vibrio cholerae, and Campylobacter spp. enteropathogens by threereaction multiplex PCR, Diagn. Microbiol. Infect. Dis., 2009, 63, 1-9.

7 J. B. Kaper, J. P. Nataro and H. L. Mobley, Pathogenic Escherichia coli, Nat. Rev. Microbiol., 2004, 2, 123-140.

8 R. A. Wilson and D. H. Francis, Fimbriae and enterotoxins associated with Escherichia coli serogroups isolated from pigs with colibacillosis, Am. J. Vet. Res., 1986, 47, 213-217.

$9 \mathrm{X}$. Ruan and W. Zhang, Oral immunization of a live attenuated Escherichia coli strain expressing a holotoxinstructured adhesin-toxoid fusion (1FaeG-FedF-LTA 2 :5LTB) protected young pigs against enterotoxigenic E. coli (ETEC) infection, Vaccine, 2013, 31, 1458-1463.

10 R. I. Walker, An assessment of enterotoxigenic Escherichia coli, and Shigella, vaccine candidates for infants and children, Vaccine, 2015, 33, 954-965.

11 J. S. Suh, W. H. Hahn and B. S. Cho, Recent advances of oral rehydration therapy (ORT), Electrolyte Blood Pressure, 2010, 8, 82-86.

12 K. Reddy, G. K. Mohan, S. Satla and S. Gaikwad, Natural polysaccharides: versatile excipients for controlled drug delivery systems, Asian J. Pharm. Sci., 2011, 6, 275-286.

13 A. I. F. Vázquez, C. M. D. Sánchez, N. G. Delgado, A. M. S. Alfonso, Y. S. Ortega and H. C. Sánchez, Antiinflammatory and analgesic activities of red seaweed Dichotomaria obtusata, Braz. J. Pharm. Sci., 2011, 47, 111-118.

14 S. Kumaran, B. Deivasiganiani, K. Alagappan, M. Sakthivel and R. Karthikeyan, Antibiotic resistant Esherichia coli strains from seafood and its susceptibility to seaweed extracts, Asian Pac. J. Trop. Med., 2010, 3, 977-981.

15 T. Sweeney, S. Dillon, J. Fanning, J. Egan, C. J. O'Shea and S. Figat, Evaluation of seaweed-derived polysaccharides on indices of gastrointestinal fermentation and selected populations of microbiota in newly weaned pigs challenged with Salmonella typhimurium, Anim. Feed Sci. Technol., 2011, 165, 85-94.

16 R. Bouhlal, C. Haslin, J. C. Chermann, S. Colliec-Jouault, C. Sinquin and G. Simon, Antiviral activities of sulfated polysaccharides isolated from Sphaerococcus coronopifolius (Rhodophytha, Gigartinales) and Boergeseniella thuyoides (Rhodophyta, Ceramiales), Mar. Drugs, 2011, 9, 1187-1209.

17 E. Hussain, L. J. Wang, B. Jiang, S. Riaz, G. Y. Butt and D. Y. Shi, A review of the components of brown seaweeds as potential candidates in cancer therapy, RSC Adv., 2016, 6, 12592-12610.

18 Z. J. Wang, J. H. Xie, S. P. Nie and M. Y. Xie, Review on cell models to evaluate the potential antioxidant activity of polysaccharides, Food Funct., 2017, 8, 915-926.

19 Anonymous China fisheries yearbook, China Agricultural Press, 2016.

20 C. L. Shi, T. M. Pan, M. J. Cao, Q. M. Liu, L. J. Zhang and G. M. Liu, Suppression of Th2 immune responses by the sulfated polysaccharide from Porphyra haitanensis in tropomyosin-sensitized mice, Int. Immunopharmacol., 2015, 24, 211-218.

21 Q. M. Liu, Y. Yang, S. J. Maleki, M. Alcocer, S. S. Xu, C. L. Shi, M. J. Cao and G. M. Liu, The anti-food allergic activity of sulfated polysaccharide from Gracilaria lemaneiformis is dependent on immunosuppression and inhibition of p38 MAPK, J. Agric. Food Chem., 2016, 64, 4536-4544.

22 M. M. Bradford, A rapid and sensitive method for the quantification of microgram quantities of protein utilizing the principle of protein-dye binding, Anal. Biochem., 1976, 72, 248-254.

23 Y. Geng, L. Xing, M. Sun and F. Su, Immunomodulatory effects of sulfated polysaccharides of pine pollen on mouse macrophages, Int. J. Biol. Macromol., 2016, 91, 846-855.

24 J. Qian, L. Xu, X. Sun, Y. Wang, W. Xuan and Q. Zhang, Adiponectin aggravates bone erosion by promoting osteopontin production in synovial tissue of rheumatoid arthritis, Arthritis Res. Ther., 2018, 20, 26-36.

25 H. K. Yakob, A. M. Uyub and S. F. Sulaiman, Immunestimulating properties of $80 \%$ methanolic extract of Ludwigia octovalvis against Shiga toxin-producing $E$. coli O157:H7 in Balb/c mice following experimental infection, J. Ethnopharmacol., 2015, 172, 30-37.

26 Healthy-lifestyle counselling, World Health Organization, 2018, http://120.52.51.13/apps.who.int/iris/bitstream/ handle/10665/260422/WHO-NMH-NVI-18.1-eng.pdf? sequence $=1 \% 20-\% 20166 \mathrm{k}$.

27 Q. M. Liu, S. S. Xu, L. Li, T. M. Pan, C. L. Shi, H. Liu, M. J. Cao, W. J. Su and G. M. Liu, In vitro and in vivo immunomodulatory activity of sulfated polysaccharide from Porphyra haitanensis, Carbohydr. Polym., 2017, 165, 189-196.

28 A. C. Leódido, L. E. Costa, T. S. Araújo, D. S. Costa, N. A. Sousa and L. K. Souza, Anti-diarrhoeal therapeutic potential and safety assessment of sulphated polysaccharide fraction from Gracilaria intermedia seaweed in mice, Int. J. Biol. Macromol., 2017, 97, 34-45.

29 D. Anderson and A. Siwicki, Basic haematology and serology for fish health programs, in Diseases in Asian Aquaculture II, ed. M. Shariff, J. R. Auther and R. P. Subasinghe, Asian Fisheries Society, Philippines, 1995, pp. 185-202.

30 R. Yuhan, A. Koutsouris, S. D. Savkovic and G. Hecht, Enteropathogenic Escherichia coli-induced myosin light chain phosphorylation alters intestinal epithelial permeability, Gastroenterology, 1997, 113, 1873-1882.

31 J. S. Maciel, L. S. Chaves, S. Bws, B. W. S. Souza, D. I. A. Teixeira, A. L. P. Freitas and J. P. A. Feitosa, 
Structural characterization of cold extracted fraction of soluble sulfated polysaccharide from red seaweed Gracilaria birdiae, Carbohydr. Polym., 2008, 71, 559-565.

32 J. C. Mollet, A. Rahaoui and Y. Lemoine, Yield, chemical composition and gel strength of agarocolloids of Gracilaria gracilis, Gracilariopsis longissima and the newly reported Gracilaria cf. vermiculophylla from Roscoff (Brittany, France), J. Appl. Phycol., 1998, 10, 59-66.

33 C. Rochas, M. Lahaye and W. Yaphe, Sulfate content of carrageenan and agar determined by infrared spectroscopy, Bot. Mar., 1986, 29, 335-340.

34 S. P. Gilmore, A. Gonye, E. C. Li, S. D. L. R. Espinosa, J. T. Gupton and O. A. Quintero, Effects of a novel microtubule-depolymerizer on pro-inflammatory signaling in RAW264.7 macrophages, Chem.-Biol. Interact., 2018, 280, 109-116.

35 A. H. Cruz, R. Z. Mendonça and V. L. Petricevich, Crotalus durissus terrificus venom interferes with morphological, functional, and biochemical changes in murine macrophage, Mediators Inflammation, 2014, 2005, 349-359.

36 O. Cirioni, A. Giacometti, R. Ghiselli, F. Mocchegiani, A. Fineo and F. Orlando, Single-dose intraperitoneal magainins improve survival in a Gram-negative-pathogen septic shock rat model, Antimicrob. Agents Chemother., 2002, 46, 101-104.

37 M. L. Kruzel, Y. Harari, D. Mailman, J. K. Actor and M. Zimecki, Differential effects of prophylactic, concurrent and therapeutic lactoferrin treatment on LPS-induced inflammatory responses in mice, Clin. Exp. Immunol., 2002, 130, 25-31.

38 P. M. Becker, H. C. Widjajagreefkes and P. G. van Wikselaar, Inhibition of binding of the AB5-type enterotoxins LT-I and cholera toxin to ganglioside GM1 by galactose-rich dietary components, Foodborne Pathog. Dis., 2010, 7, 225-233.

39 F. Alsaedi, D. P. Vaz, D. H. Stones and A. M. Krachler, 3Sulfogalactosyl-dependent adhesion of Escherichia coli HS multivalent adhesion molecule is attenuated by sulfatase activity, J. Biol. Chem., 2017, 292, 19792-19803.

40 C. Gonçalves, F. Berthiaume, M. Mourez and J. D. Dubreuil, Escherichia coli, STb toxin binding to sulfatide and its inhibition by carragenan, FEMS Microbiol. Lett., 2008, 281, 30-35.

41 H. R. Sinclair, C. W. Smejkal, C. Glister, F. Kemp, H. E. Van Den, J. Slegte, G. R. Gibson and R. A. Rastall, Sialyloligosaccharides inhibit cholera toxin binding to the GM1 receptor, Carbohydr. Res., 2008, 343, 2589-2594. 